\title{
Women Founders in the Technology Industry: The Startup-Relatedness of the Decision to Become a Mother
}

\section{Katherina Kuschel ${ }^{\mathbb{D}}$}

Dirección de Investigación y Desarrollo Académico, Universidad Tecnológica Metropolitana, Santiago 8330378, Chile; kkuschel@utem.cl; Tel.: +56-9-525-800-35

Received: 5 March 2019; Accepted: 28 March 2019; Published: 1 April 2019

\begin{abstract}
This paper explores the decision to become a mother among women in the technology industry, particularly if there is an "optimal context" regarding startup development (business stage and size). Eighteen interviews were conducted with an international sample of women founders and analyzed using a grounded theory approach. Findings suggest two sources of "mumpreneurs" in technology ventures: (1) women who created a startup while young and childless, postponing maternity until the business is "stable"; and (2) mothers who created a technology venture as a strategy to gain higher levels of flexibility and autonomy than they experienced in the corporate world. The first group is highly work-role salient, while the second is highly family-role salient. The results of this work contribute to theory development by revealing the "startup-relatedness" of family decisions by women founders in the technology industry. I offer recommendations of how accelerators can improve mentorship for women in high-growth technology ventures and unleash women's potential.
\end{abstract}

Keywords: entrepreneurship; new high-technology ventures; women founders; motherhood; decision-making; role salience; mumpreneurs; startups

With the introduction of the Internet and related technologies into the market, the industry of startups arose. A startup is a short-term-and often informal-organization that seeks to create a product under conditions of high uncertainty. Globally, national public policy, many business schools and corporations, and some industries have embraced this type of organization. It has been documented that high rates of entrepreneurship with an innovation component play a critical role in the wealth of nations, economic dynamism (Decker et al. 2014), and job creation (Kuschel et al. 2018).

Moreover, and parallel with the increased number of women in science, technology, engineering, and mathematics (STEM), more startups are being led by women. Still, according to the estimations of Robb and Coleman (2009), only 5-6\% of high-technology entrepreneurs are women, and about $3-5 \%$ of incubated and accelerated projects are led by women. Start-Up Chile, a public accelerator in South America, bucks that trend, with around 20\% women founders and $8.9 \%^{1}$ women-led startups (Kuschel and Labra 2018). In general, though, women are poorly represented in these spaces. Uncertainty, competitiveness, aggressiveness, and fast pace are characteristics of the high-growth technology industry.

The "masculine" and "male-dominated" features of the environment raises the question of whether the technology industry is welcoming to women who expect to become mothers.

1 Number calculated by Kuschel and Labra (2018) with data provided by Start-Up Chile accelerator, since the 1st generation to the 11th (2173 founders, and 972 startups supported by the program), as of March 2015. 
The motherhood decision is defined as the choice to forego, start, or enlarge a family (Prunty et al. 2008). Also, some investors (e.g., public funds, business angels, venture capitalists) might not fund women-led startups because of the potential for the leader to get pregnant and leave the startup a lower priority, at least temporarily (Kuschel and Lepeley 2016b).

This article does not directly examine women's participation in tech. The aim of this study is to explore the conditions under which women decide to have children in one extreme case-women leading a startup in the technology industry. Do women postpone maternity in the technology industry?

First, this study provides a literature review on startups functioning, the profile of women in the technology industry, and the decision to become a mother for those involved as business founders in the technology industry. After the theoretical and methodological sections, the findings are presented. Two main paths into being "mumpreneurs" are found, those entering business ownership before having children and those entering business ownership because of their mothership. Within the study, the authors find that the former group can be further broken down into subgroups depending on the development stage of their business. Finally, suggestions are proposed for support of such entrepreneurs and also future directions for research.

\section{Literature Review}

\subsection{Business Stages at a Technology Startup}

A new high-technology venture (NHTV) or startup is defined as a business model (Blank 2010) that is profitable, repeatable, and scalable ${ }^{2}$. At its beginning, a startup is an informal business with a small team. The goal of the startup is to create technology or to leverage a business model based on technology to make money. There are three broad business stages for startups: product development, growth, and heavyweights. First, the "product development" stage includes the ideation, working prototype in development and prototype validation, functional product with users, and business model validation (also known as the search for market fit). Founders in the product development stage are searching for seed funding because the companies are not yet economically sustainable. Early-stage investors respond strongly to information about the founding team rather than to traction or previous investors (Bernstein et al. 2017), which is a critical factor for women founders (Kuschel et al. 2017). Second, the "growth stage" of a tech startup includes scaling sales and raising capital. Normally, entrepreneurs "pitch" 3 to investors, trying to attract interest by exhibiting their startup's "traction"4 In this stage, startups raising venture capital (VC) must incorporate to receive funding from private investors. Investors also give access to a significant network, mentorship, board, and assistance in decision-making in exchange for equity (business participation) and/or return on investment. Third, "heavyweights" sell the company (exit strategy), acquire other startups, or make an initial public offering (IPO). The dynamic environments in which these companies are inserted make most traditional management methods obsolete (Ries 2011). The participants in this study are leading startups in the product development and growth stages.

\subsection{Women in New High-Technology Ventures}

For many years, women's spectacular progress in business ownership has been virtually invisible in mass media and academic journals in the U.S. (Baker et al. 1997). A recent review of the literature on startups and gender (Kuschel and Lepeley 2016a) identified that most studies were concentrated

2 Coaching, consulting, and freelancing are not considered startups—although they may use technology—because they do not have the potential for scaling. They are self-employed.

3 The pitch is a short $(2-3 \mathrm{~min})$ presentation of the business plan.

4 The traction is the validation of the product or business model. It consists in metrics of market demand (i.e., profit, revenues, active users, registered users, engagement, partnerships/clients, traffic) used to convince investors of the startup potential. 
in the U.S., and there is little knowledge of startups in Europe and emerging economies [such as Latin America, BRIC (Brazil, Russia, India, China), and MENA (Middle Eastern and North African countries $^{5}$ ]. In most of those studies, startup performance was compared without reference to the perspectives of women entrepreneurs in technology (Singh Cassidy 2015).

Lately, new evidence has shown that women leading tech ventures face gender-based stereotypes. This affects how these women design their teams, raise capital, and grow their businesses. Women normally build their teams based on trust, partnering with their romantic partners or close friends (Kuschel and Lepeley 2016b). Therefore, these teams are smaller, less diverse, have less credibility with potential investors, and grow more slowly than male-led teams (Kuschel and Labra 2018; Kuschel and Lepeley 2016b; Kuschel et al. 2017). However, women-led startup teams contribute to job creation (Kuschel et al. 2018), and a third of women-led startups keep raising funds after acceleration (Kuschel et al. 2017).

Women must surmount several obstacles to be part of the growth of women's business ownership. The masculinization of entrepreneurship-including stereotypical masculine behaviors such as aggressiveness, assertiveness, independence, and self-confidence-generates serious difficulties for women who wish to engage in entrepreneurial activities (Ahl 2002; Bird and Brush 2002; Eagly and Johannesen-Schmidt 2001). Moreover, women's perceived capabilities (a type of human capital) and economic participation both play roles in influencing the start-up rates of women entrepreneurs (Brush et al. 2017). The constant comparison also ends up becoming a trap. Researchers and society both tend to overlook the complexity and variety of women entrepreneurs, and women become "victims of the male norm" (Billing 2011).

Historically, self-employed women were less likely than men to become small business owners due to societal and patriarchal pressures (Marlow 1997) that acted as discriminatory barriers at all business stages. A proven barrier for women's small business growth has been limited access to financial resources (Carter and Allen 1997; Brush et al. 2004), and this is true for women founders of technology ventures as well (Demartini 2018; Demartini and Marchegiani 2018).

Women who do participate in business incubator or startup acceleration programs are often exhibited as "tokens" to illustrate gender diversity. This visibility may have negative consequences for the founder. Tokenism affects women's "sense of fit" and draws attention away from their businesses (Marlow and McAdam 2012).

Nevertheless, there are some successes specific to women in tech startups. Unlike gender discrimination in traditional investment settings, crowdfunding has been found to be a great tool for women in the early stages of raising capital (Gorbatai and Nelson 2015). According to Gorbatai and Nelson (2015), donation-based crowdfunding sites offer a completely different institutional setting in which to obtain funding for new small businesses or products, bypassing many risks and difficulties inherent in traditional methods of fundraising, as success depends much more on written language rather than visual and verbal cues.

Nowadays, research on women's entrepreneurship is growing (Jennings and Brush 2013), but there are still some gaps, particularly regarding women-led startups (Kuschel and Lepeley 2016a) in developing countries (Bullough 2013) and from a feminist perspective (Marlow and McAdam 2012, 2015).

\subsection{The Decision to Become a Mother}

Previous studies explore how dominant discourses of mothering influence women in their life decisions about children. Most evidence indicates that all women negotiate dominant

5 Brazil, Russia, India and China (BRIC) show a similar stage of development. Middle East and North African (MENA) region has $60 \%$ of the world's oil reserves and $45 \%$ of the world's natural gas reserves. MENA region shows newly advanced economic development yet some areas are still in conflict. 
ideals of a "good mother" and a "self-sacrificing mother" (Knaak 2010). However, as noted by Maher and Saugeres (2007) after analyzing the fertility decision-making of 100 Australian women, such stereotypes need to be further broken down, since women with and without children respond to different aspects of such ideals. For women who have children, images of the "good mother" are less prevalent than pragmatic concerns about how to manage mothering. In contrast, childless women understand mothering as all-encompassing and potentially overwhelming. Nevertheless, fertility decision-making is often situational and affected by social expectations and employment conditions (Maher and Dever 2004) instead of influenced by specific policies.

Despite significant changes to women's involvement in the public sphere, cultural discourses of femininity still highlight motherhood, which has been perceived as "natural" for women. Consequently, women who choose not to have children are viewed as abnormal or deviant (Gillespie 2000). Nowadays, postfeminist approaches or "choice" feminism is installing a new gender order of "self-determining, individuated, and empowered" women (Budgeon 2015), which, blended with the previous feminist perspectives, presents "disparate discourses around contemporary mothering" (Vincent et al. 2004). This has led to both an entrepreneurialization of motherhood (Thornton 2011) and new forms of entrepreneurial feminities (Byrne et al. 2019; Lewis 2014).

On average, Latin American women in the technology sector have higher levels of education and represent upper-middle socioeconomic status (Kuschel and Labra 2018), are a cohort with lower fertility rates (Adsera and Menendez 2011), and may be less influenced by Latino and macho culture (Susaeta et al. 2013) than Latina women not in the tech sector.

When is the optimal time to become an entrepreneur? Motherhood can also serve as a trigger to start a business, as women seek greater autonomy and time flexibility via self-employment (Annink and Dulk 2012; Loscocco 1997). Greene et al. (2013) explore how stereotypes and role expectations influence women's propensity toward entrepreneurial activity: "Maternal self-employment has a counter-stereotypical effect, and so positively influences daughters to become self-employed."

\subsection{Theoretical Framework: Testing the Family Embeddedness Theory}

This study combines two frameworks; role salience within social identity theory and family embeddedness. First, the importance of a role or "role salience" is "determined by commitment to the role, which includes attitudes and emotions, participation in the role, and knowledge about the role. An important issue in career development is how individuals integrate the various life roles" (Matzeder and Krieshok 1995, p. 333). According to social identity theory, whether or not men and women report key roles as similarly salient, and how they define, enact, and manage these roles, may differ substantially (Cook 1994). These individual ways of "doing gender" (West and Zimmerman 1987) significantly impact women's success.

Some studies find relations between family factors and starting a new business (Boden 1996, 1999; Brown et al. 2006; Green and Cohen 1995) or becoming self-employed (Carr 1996). Loscocco (1997) argues that women may make the decision to start their own businesses because they need more flexibility to meet family demands and responsibilities.

The family embeddedness perspective of entrepreneurship (Aldrich and Cliff 2003) portrays entrepreneurs' family and business domains as highly interrelated. Business owners can structure their work according to personal preferences (Bird and Brush 2002), whereas organizational employees have less control over flexibility and autonomy. Moreover, entrepreneurs may more easily transfer human, social, and financial resources between their family and business domains (Danes et al. 2009).

Similarly, Greenhaus and Powell (2012) suggest that individuals may have family considerations that influence work decisions, such as job relocation, whether to quit a job, pursue a new job opportunity, seek part-time employment, interrupt paid employment, or start a new business. They call this the "family-relatedness of work decisions." However, further research is still needed to understand how the decision-making process is different according to work, industry, individual, family, and social variables (Powell and Greenhaus 2012). 
This study tests the "family-relatedness of work decisions" by exploring the extreme case of women in a very demanding environment with economic constraints, long working hours, and high time pressure for developing a product and getting users. The results of this work expand the family-embeddedness perspective and contribute to theory development by revealing the decision of women founders to become a mother while working in the technology industry.

\section{Methodology}

The current study was designed with a qualitative, inductive, and constructive approach. In 2014 and 2015, I explored the experiences of an international sample of women entrepreneurs in technology; most of the participants were beneficiaries of Start-Up Chile.

\subsection{Sample}

Participant selection criteria: This study gathered data from women founders of startups. Most of the participants of the study were benefited by Start-Up Chile (SUP), an international acceleration program located in Santiago de Chile. A snowball technique was used to find mothers. I initially found six mothers leading startups, only two of whom were from Chile originally. Therefore, I decided to expand the sample by interviewing women founders without children on their decision to become mothers; these participants are included in the sample. SUP has an international focus, which is reflected in the mixed-country sample. Table 1 presents both the business and founder's characteristics. As shown in Table 1, I conducted 18 interviews, including with women that were solo founders $(n=4)$ or members of the founding team $(n=14)$. Six founders $(33 \%)$ had no employees or freelancers, either because of the early stage of the startup (product development stage) or because of an eventual pivot or exit. Of the participants, 50\% $(n=9)$ of this study were leading startups in the growth stage. They were from nine different countries of origin, yet most were contacted while being accelerated and therefore located in Santiago, with ages ranging from 26 to $40 ; 28 \%(n=5)$ had a STEM educational background and 50\% $(n=9)$ had studied business. Finally, $41 \%(n=6)$ of them were mothers.

Interview design considerations: I incorporated work-family (WF) scholars' suggestions to capture heterogeneity, including single people, those with and without children, single-parent families, and dual earners in the sample (Greenhaus et al. 2000; Parasuraman et al. 1997; Voydanoff 1988; Watkins and Subich 1995). Moreover, I included women who have participated in startup accelerators (in Start-Up Chile, Wayra Chile, or other accelerators abroad) as well as women who have not, from both Latin America and abroad. The sample includes women engaged in various stages of the decision-making process of motherhood and startups from a variety of industries and stages.

Procedure: Each participant was contacted by e-mail and invited to an online interview (via Skype) in Spanish. Four interviews were conducted in English. The researcher explained the consent form verbally. The form was then signed, and a copy was delivered to the participant. All participants agreed to be audio-recorded. Each interview was transcribed semi-verbatim, excluding identifying information. The transcriptions were entered into ATLAS.ti v.7.0 software for qualitative analysis. The questions cover the topics of motivation to startup a technology venture, team composition, and motherhood expectations. A few sample questions: What are your future growth expectations for this venture? Do you see yourself as a mother? What are the pros and cons that this industry offers mothers? As a women startup founder, did you confront special challenges when becoming a mother (if you did)? 
Table 1. Sample characteristics.

\begin{tabular}{|c|c|c|c|c|c|c|c|c|c|c|c|c|}
\hline \multirow[b]{2}{*}{$\begin{array}{l}\text { Founder } \\
\text { ID }\end{array}$} & \multirow[b]{2}{*}{ Country } & \multicolumn{7}{|c|}{ Business Characteristics } & \multicolumn{4}{|c|}{ Founder Characteristics } \\
\hline & & Industry & Cofounders & Employees & $\begin{array}{l}\text { Work } \\
\text { Role }\end{array}$ & $\begin{array}{l}\text { Team Gender } \\
\text { Diversity }\end{array}$ & Accelerated & Business Stage & Age & $\begin{array}{l}\text { Educational } \\
\text { Background }\end{array}$ & $\begin{array}{c}\text { Marital } \\
\text { Status }\end{array}$ & $\begin{array}{l}\mathbf{N}^{\circ} \text { of } \\
\text { Children }\end{array}$ \\
\hline CA & Chile & Biotechnology & 1 & 0 & $\mathrm{COO}$ & Mixed & Wayra & Product development & 28 & STEM & Single & 0 \\
\hline AS & Venezuela & Health & 5 & 0 & CEO & Mixed & SUP & Product development & 26 & Industrial Design & Single & 0 \\
\hline LF & USA & Energy & 2 & 0 & $\mathrm{COO}$ & Mixed & SUP & Product development & 31 & Communications & Single & 0 \\
\hline MA & Pakistan-UK & MarketPlace & 1 & 0 & $\mathrm{CEO}$ & Female & SUP & Product development & 29 & Business & Single & 0 \\
\hline $\mathrm{AM}$ & USA & Services & 3 & 1 & CEO & Mixed & SUP & Product development & 26 & Business & Single & 0 \\
\hline $\mathrm{CM}$ & Argentina & eCommerce & 2 & 8 & CEO & Mixed & SUP & Growth stage & 32 & Business & Married & 0 \\
\hline PC & Chile & Education & 2 & 4 & CEO & Mixed & - & Growth stage & 31 & STEM & Married & 0 \\
\hline DG & Chile & eCommerce & 3 & 35 & $\mathrm{CMO}$ & Mixed & SUP & Growth stage & 30 & Communications & Married & 1 \\
\hline SC & Argentina & Software & 4 & 6 & $\mathrm{COO}$ & Mixed & SUP & Growth stage & 32 & Business & Married & 1 \\
\hline VK & Argentina & Services & 3 & 2 & CEO & Female & - & Product development & 40 & Business & Divorced & 1 \\
\hline CA & Chile & Software & 3 & 4 & CEO & Mixed & SUP & Growth stage & 36 & STEM & Single & 0 \\
\hline $\mathrm{CN}$ & Mexico & Services & 3 & 0 & CEO & Mixed & SUP & Exit strategy & 33 & Business & Single & 0 \\
\hline GV & Estonia & MarketPlace & 3 & 2 & $\mathrm{COO}$ & Mixed & - & Growth stage & 29 & Business & Single & 0 \\
\hline KD & Chile & Biotechnology & 3 & 6 & CEO & Mixed & SUP & Growth stage & 26 & STEM & Single & 0 \\
\hline $\mathrm{LC}$ & Argentina & Software & 4 & 6 & CEO & Mixed & SUP & Growth stage & 32 & Business & Cohabit & 0 \\
\hline $\mathrm{FH}$ & Morocco-Chile & MarketPlace & 1 & 0 & $\mathrm{CEO}$ & Female & SUP & Product development & 32 & STEM & Married & 2 \\
\hline VH & Brazil & Services & 2 & 5 & CEO & Mixed & - & Product development & 28 & Business & Married & 1 \\
\hline VM & Venezuela & MarketPlace & 1 & 6 & CEO & Female & Other & Growth stage & 32 & Communications & Single & 1 \\
\hline
\end{tabular}




\subsection{Analysis}

The analysis of data used a grounded theory approach (Glaser and Strauss 1967) as a way of arriving at a theory when there were no (or few) previous theoretical frameworks. The theory provided explanatory power by including controllable and access variables if they did not emerge by themselves. In addition, a particular interest was to find the "hidden assumptions" of various participants (Charmaz 2006). I conducted a first open coding, inductively, trying to identify emerging topics. Significant paragraphs (quotes) were selected and categorized into codes. Then, selected coding inductively identified the central category.

Figure A1 shows the emergent topics that were coded. The tag cloud is a visual depiction of content tags used in the hermeneutic unit. More frequently used tags are depicted in a larger font, and the display order is alphabetical. The tag cloud allowed me to find a tag both by alphabet and by frequency. After this process, axial coding was conducted to seek the relationship between categories and sub-categories. Families of codes were built with related codes.

The "network of codes" in Figure A2 is a visual representation of the type of link (axial coding) relating significant codes. Then, selected coding identified the central category, which interpreted the studied phenomena. The co-occurrent and neighbor codes were explored around the central category.

Lastly, a discriminant analysis was conducted to test if this theory fit a different sample. Constant comparative analysis (Corbin and Strauss 2008) was conducted to determine consistency between codes and the data. The goal was to gather the women founders into categories that shared similar characteristics, and it can be read as a time line from the left to the right. The analysis revealed that motherhood-related expectations often co-occur and overlap with their business stage.

\section{Findings}

Two configurable patterns were found that led to the outcome of entrepreneurs in technology who were mothers: (1) women who created a startup while young and childless, and (2) women who created a technology venture while a mother. Table 2 summarizes the particular characteristics that distinguish each category.

Table 2. Emerging categories and its characteristics.

\begin{tabular}{|c|c|c|c|c|c|}
\hline \multirow{2}{*}{$\begin{array}{c}\text { Category } \\
\text { Subcategory }\end{array}$} & \multicolumn{4}{|c|}{ 1. Women Creating a Startup While Young and Childless } & \multirow{2}{*}{$\begin{array}{l}\text { 2. Women Creating } \\
\text { a Tech Venture } \\
\text { While a Mother } \\
2\end{array}$} \\
\hline & 1.1 & 1.2 & 1.3 & 1.4 & \\
\hline $\begin{array}{l}\text { Motherhood } \\
\text { Expectations }\end{array}$ & $\begin{array}{l}\text { Not thinking about } \\
\text { motherhood }\end{array}$ & $\begin{array}{l}\text { Wishing to be a } \\
\text { mother }\end{array}$ & Mother & $\begin{array}{c}\text { Women with } \\
\text { conditions to be a } \\
\text { mother }\end{array}$ & $\begin{array}{l}\text { Women who create a } \\
\text { technology venture } \\
\text { while being a mother }\end{array}$ \\
\hline Business Stage & $\begin{array}{c}\text { Product } \\
\text { Development }\end{array}$ & Growth & $\begin{array}{l}\text { incorporated, raising } \\
\text { capital, scaling }\end{array}$ & Growth & Any \\
\hline Team Size & 1 to 5 & $\begin{array}{c}1-2 \text { cofounders, } \\
\text { some freelancers (as } \\
\text { employees) }\end{array}$ & $\begin{array}{l}\text { 3-4 cofounders with } \\
\text { employees }\end{array}$ & $\begin{array}{c}3-5 \text { cofounders with } \\
\text { employees }\end{array}$ & $\begin{array}{l}\text { 1-2 cofounders, } \\
\text { some freelancers (as } \\
\text { employees) }\end{array}$ \\
\hline Team Gender & Mixed & Mixed & Mixed & Mixed & Mixed \\
\hline Avg. Age & 28 & 31.5 & 34 & 31 & 31 \\
\hline Work Role & $\mathrm{CEO}, \mathrm{COO}$ & $\mathrm{CEO}$ & $\mathrm{CEO}, \mathrm{CMO}, \mathrm{COO}$ & $\mathrm{CEO}, \mathrm{COO}$ & $\mathrm{CEO}$ \\
\hline
\end{tabular}

\subsection{Women Creating a Startup While Young and Childless}

Four subcategories divide this main category and can be conceived as continuous stages. The axial and selected coding revealed that motherhood expectations of women entrepreneurs in tech are: "not thinking about motherhood," "wishing to be a mother," "mother," and "women with conditions to become mothers", and that those codes are associated with the business stage of the startup.

\subsection{Not Thinking about Motherhood}

Young and single is the common profile of women founders. For them, motherhood is not an issue. They are young (average age 28) and ambitious. As their startups are still in the product development 
stage, they do not have employees. Their work role is highly salient, and they prioritize traveling and personal development.

"Yes, I can see myself being a mother in the future, but I feel like right now is a very freeing moment." AS, 26, single, childless, chief executive officer (CEO), health devices

"Yes. I can see myself as a mother. Well, I'm already 31 years old ... (Laughter). Umm ... I think I'm scared of it, but mainly because of my lifestyle. I travel a lot and I have a roommate ... " LF, 31, single, childless, chief operating officer (COO), energy

\subsection{Wishing to Be a Mother}

These are women (average age 31.5) in romantic relationships. They have great expectations for being mothers. As they are hiring employees and raising capital from investors, they are postponing maternity and hiding their true family expectations from them.

"I'm a woman, I'm 32 years old, I've been married for two years, and of course I think about having children. I still don't know how I will make the pieces fit (... ) I feel like I'm postponing it. If it weren't at [the startup] I probably would already have had a child. I did delay it a bit, but I'm not going to abandon it (...) During the first investment round they asked me about it. They said, 'Are you thinking about having children?' I didn't take it very well. (... ) All the investors at the moment (three) were men, and they said they wouldn't invest if it were the case. I didn't like that comment at all, I took it poorly and I said, 'Look, I can't promise anything. I'm 31 years old. What I can promise, however, is that I won't have any children a year from now.' It wasn't in my interest to have a baby, but that doesn't mean I could have one in two years. And the truth is I want to have a family, and I know I will. What I'm trying to do is build a good, profitable business. I believe things will shape up eventually." CM, 32, married, childless CEO, eCommerce

\subsection{Mother}

When the business is incorporated, "stable", and the team is growing (has fixed employees), women (average age 34) take the next step toward motherhood and get pregnant. Particularly for women in this category, teams are bigger and more diverse in gender. The interviewer asked whether it was possible to have a baby at the early stage of her startup.

"No, impossible, no. We work there 24/7. (... ) What we did was look for people to cover for us in these two key areas. We hired a CEO and a COO to lighten up work and so I could spend more time with my baby. (... ) You never should have a child during your first year of launching a startup unless your parents live very close or you hire external help." DG, 30, married, mother, chief marketing officer (CMO), eCommerce

They work "until the last day" before giving birth.

"At first it was very tough. I got pregnant last summer and worked until the last day. Prenatal leave does not exist ... I worked until a week before I gave birth." DG, 30, married, mother, CMO, eCommerce

"I worked until I had my C-section (... ). I almost had to drive to my own C-section." VK, 40, divorced mother, $\mathrm{CEO}$, investment

They take a short maternity leave (one to three months).

"I used to say, 'I'll have the baby and return to work in a month,' but you never know how important work is and how it changes your life. (... ) It was very hard for me; I had to go back to work as soon as possible. And you pressure yourself that way, and with a baby ... " DG, 30, married, mother, $\mathrm{CMO}$, eCommerce

"I went back to work three months after having my son." VK, 40, divorced, CEO investment 


\subsection{Women with Conditions Placed on Being a Mother}

The discriminant analysis resulted in a fourth group (1.4). This group did not fit in any category above, although they did share the same business characteristics (business stage, team size, team gender) as the group of mothers (1.3) - they were single or cohabitating for a short period, and they did not have children. Their average age was 31 years old.

"Now it's a problem. I do want to have children now, but it's complicated because I'm single. But it is a problem for me, and a constant worry. For example, I want to travel to the U.S. for some time, to open a new office. And I think, 'It has to be really quick,' because I want to be a mother and I'm already 35 . So I'm running out of time." CA, 35 , single, childless, CEO, software as a service

\subsection{Women Who Create a Technology Venture While Already a Mother}

Another discriminant analysis showed the second path-women who create a technology venture while already a mother. Most have become first-time mothers and are creating a startup because of the time flexibility and autonomy it affords them with the ability to work anywhere. These factors are valued as great benefits that facilitate the meeting of demands from the startup and the home. All of the participants in this category were well-educated women with long work experiences in the corporate world. They left their jobs with a deep knowledge of the industry. Their average age was 30.6 years old.

"I worked as a Communications Director at a multinational company. I got pregnant while I was there. I took my pre-and post-natal maternity leave and returned to the company. I left someone taking care for my baby, along with my mother. It was very tough, since I had long work hours. I was home late and the baby would be sleeping, so I decided to become an entrepreneur." VM, 32, single, mother, CEO, marketplace

\subsection{Flexibility and Autonomy}

Women with and without children value flexibility and autonomy as working conditions that allow them to balance family life and a startup. Particularly, among women who worked in the corporate world, there was a desire for independence that strengthens the argument for autonomy.

"One of the advantages of being an entrepreneur is the flexible schedule. It was one of the reasons I decided to start my own company." PM, 30, married, childless, CEO, education platform

"It's very hard to balance maternity and startups ... it has its pros and cons. The good part is that I can get home by 2 pm and then spend the afternoon with him [the baby]. (... ) I went back to work after two months ... my friends are mothers too, and they would tell me I was crazy. But now they return to work after six months of maternity leave and they [her girlfriends who are employees] feel terrible because they work until $7 \mathrm{pm}$ and they have to leave their babies at home. At least I can manage my schedule; if I want to take him to the pediatrician, I can. At this stage, now the baby is six months, I feel like I'm at the best work-family situation. Four months ago, I was in the worst." DG, 30, married, mother, $\mathrm{CMO}$, eCommerce

"Irony lies in the fact that you can find something in technology that you might not be able to find in any other type of business. It's not physical labor. It's true that you work for many hours, but those are hours that can be spread out. My cellphone is my main tool for work. I can be waiting in line to pick up my daughter [from school] and take that time to answer emails and listen to things. You can take advantage of those moments, and that is all thanks to technology. So it is ironic [that] there aren't more women and mothers in technological entrepreneurship." VM, 32, single, mother, $\mathrm{CEO}$, marketplace 


\subsection{Family Sacrifices}

Nevertheless, sacrifices must be made to achieve company success. An example of such sacrifice is offered by one women founder who had to leave her baby back in Argentina—her home country—in order to raise venture capital in the U.S.

"Yes, it was tough because they grow up so much in a couple of months! When I left, she slept in a crib and didn't speak. After four months she spoke, she slept in a bed; she wasn't a baby anymore. She still calls me 'Dad' (laughter). (... ) For me, leaving for four months wasn't cheap, and I'm not speaking in terms of money. Coming back and her calling me 'Dad,' I don't know. Going back to that routine of waking up at night when she cried. Obviously, I'm responsible for the decisions I make, but there are sacrifices you make, and you have to pay for them. At a moment I decided that she wouldn't have a mom for four months, but not for her entire life, and I wouldn't tell her, 'I stopped doing something for you.' Let her carry that guilt around the rest of her life, because it was a great opportunity for me; you don't always get invited to programs at Silicon Valley. So instead I preferred to say, 'Nothing will happen to her in four months.'" SC, 32, married, one child, COO, software as a service

This case illustrates the pervasive effects of the startup on the family, and in this sense, it directly challenges Aldrich and Cliff's family embeddedness perspective (2003).

\subsection{Productivity}

These family sacrifices have embedded a great opportunity cost. The resistance of the team, the couple, and the entrepreneur have been tested. Recent mothers in technology ventures acknowledge the value of quality time with their children; therefore, they try to ensure that the work done is as efficiently as possible.

"Being out of your comfort zone makes you move around, and you're constantly trying to get the best out of the situation, since you're risking a lot. In my case it was being with my daughter." SC, 32, married, one child, COO, software as a service

"I now prefer to have lunch at my desk and leave work two hours earlier in order to be with my baby." DG, 30, married, one child, CMO, eCommerce

"Having children is time-consuming and leaves you out of focus, but at the same time, it helps you clear out your mind and helps you realize what is not important. It brings you to reality, and what really matters." VK, 40, divorced, mother, CEO, investment

\section{Discussion}

We can see that among women who created a startup while young and childless (Category 1), the role salience is not a fixed category. The value placed on work and family changes through the course of life (Carlson and Kacmar 2000).

For the vast majority of the women founders, it seemed as though there was nothing more important than having a career first and postponing motherhood for as long as possible. Identity-based perspectives may provide a solid framework to understand this decision-making process. The participants who created a startup while young and childless behave consistently with the socially constructed identity (Hastie 2001) of a founder, rather than of a women founder or a potential mother.

According to social identity theory, individuals tend to invest more of themselves in roles that are highly salient (Burke and Reitzes 1991; Lobel 1991; Rothbard and Edwards 2003; Stryker and Serpe 1994). The reason is that positive experiences in highly salient roles reinforce their self-identity (Thoits 1991). Therefore, it may be argued that a strong work-role salience exists for women founders postponing maternity and taking advantage of an accelerator program (and, for instance, leaving the 
baby back in their home country), while a strong family-role salience exists for mothers who decided to leave the organizational job to create a startup.

In the second category, the motivation to start up a business is the need for flexibility and autonomy that will serve the family (Annink and Dulk 2012; Loscocco 1997). The case of Category 2 supports a family-embeddedness perspective on new venture creation (Aldrich and Cliff 2003). However, the first group of participants shows a business-relatedness of family decisions rather than a family-relatedness of work decisions (Greenhaus and Powell 2012; Powell and Greenhaus 2012). Women in both main categories have postponed maternity in pursuit of career success, defined as stability or growth. The business-relatedness of postponing maternity among women founders in the technology industry implies the use of a different lens to approach the entrepreneurial career. Particularly, mothers in group 2 are part of the less-common category, although there is a general belief that women with advanced knowledge of the industry will leave the corporate world to start a tech venture. For this group, becoming a tech entrepreneur seems to be a "career renewal," defined as "a period of doubt and self-examination that could be followed by a renewed commitment to career issues" (Bejian and Salomone 1995, p. 53). This process contributes to a richer understanding of individuals with interrupted career paths (Sullivan 1999).

Women's underrepresentation in the high-tech sector is strongly associated with their under-participation in executive boards and their exclusion from corporate management and strategy-based company and association boards (Kariv 2013, p. 493). This affirmation is true for group 2-mothers who have left jobs in organizations and set up their startups-which was represented by a smaller group of women in startups, as seen in our study. Mothers in Category 1.3 and mothers in Category 2 have followed different paths. Therefore, their team compositions and business development are radically different.

Finally, this study provides further evidence rebutting myths related to the advancement of women in STEM fields. While the author acknowledges the importance of STEM, it is possible for women who do not come from a STEM background to individually or collectively start a technology venture. Notably, in this sample, only $28 \%(n=5)$ of the participants had a STEM educational background.

\section{Conclusions}

In summary, the findings of this study showed two different configural patterns that led to the outcome of "mumpreneur" in technology: (1) women who created a startup while young and childless, becoming mothers after postponing maternity until the startup is "stable," and (2) women who created a technology venture while a mother. The first group is more work-role salient, while the second is highly family-role salient.

Three subgroups divide the first category and can be conceived of as continuous stages: "not thinking about motherhood," "wishing to be a mother," and "mother," and those stages are associated with the business stage of the startup.

All participants acknowledged flexibility and autonomy as key working conditions that allow work-family balance, although mothers acknowledge a huge family sacrifice for achieving business success, contrary to evidence from the work-family literature from the corporate or traditional entrepreneurship context.

\subsection{Theoretical Contribution to the Work-Family Field}

This study contributes to the examination of characteristics among women entrepreneurs in technology, a sample that has been generally overlooked in the work-family field. The grounded theory emerging from the data is the main contribution of this study. The data revealed that the type of mumpreneur in technology appears to determine her work or family role salience. The role salience associated with the business stage and personal development explains the decision to postpone 
maternity in the technology industry, while a separate cohort of mothers left the corporate world and created a tech venture.

The results of this work contribute to theory development by revealing a "startup-relatedness of family decisions" of women founders in the technology industry.

\subsection{Limitations and Directions for Future Research}

Because of the low number of women and mothers participating in acceleration programs, the design of this study included a mixed-country sample. This decision entails advantages and disadvantages. As an advantage, the common themes emerging from the analysis was more likely to be universal for women techpreneurs rather than simply outcomes specific to a particular situation. Future studies should address cultural and regulatory influences from the host country and/or home culture among these women and examine whether they face similar gender-related constraints. Future research might explore changes in role salience and what factors promote identity change among women founders in technology.

Do investors perceive founder role salience? How can it impact the fundraising process? As this environment might seem hostile to motherhood, research must be conducted to explore the length of time mothers maintain their entrepreneurial activity, the sustainability of being a mumpreneur in the technology industry, as well as the implications it has for their children (Schindehutte et al. 2003).

A new line of research that emerged in this study is related to the literature of success and failure-how flexibility, autonomy, wellbeing, reputation, visibility, and growth are measures of success for women "techpreneurs", as well as how work and family management styles may affect their own wellbeing differently. How do these "startuppers" manage the spillover effect to their children and the romantic and business partners? Finally, how is techpreneurship being presented as an attractive choice for mothers (Byrne et al. 2019)? Work-family issues and wellbeing is a key emerging area of research among women in entrepreneurship (Lepeley et al. 2019) and mothers in technology.

\subsection{Implications for Career Development}

Mothers categorized in the second group have left the corporate world seeking flexibility and autonomy. There is a huge opportunity for corporations to offer new "intrapreneurial career paths" for new mothers (Kuschel and Salvaj 2018). After several months, the new venture may create a spin-off and become a profitable business. This process may be supported by alliances with university accelerators and external mentors, and there is no need to add organizational institutions to support spin-offs.

\subsection{Recommendations for Policymakers and Managers of Accelerator Programs}

These results indicating that women postpone maternity until their startup is growing may give rise to contradictory interpretations. On one hand, people may assume that single and childless women are more suitable as founders. On the other, the low participation of mothers in the technology sector reflects a highly competitive and hostile environment for both women and mothers. The findings should be carefully analyzed. The solution of a cultural change towards a shared responsibility of family roles, family leave, paternity leave, and flexi-time to both men and women in the workforce may help them decide to accelerate their family decisions. Yet, the profile of highly educated women, such as the ones of this sample, have many resources, and contrary to women with low levels of education, they tend to postpone maternity (Gustafsson and Kalwij 2006).

My suggestion is to create a group of mentors as part of the other resources provided by the accelerator who can serve as role models and offer advice to founders with motherhood expectations. Mentorship is a key element of an enabling entrepreneurship ecosystem for women (Kuschel 2019). This will help women who are struggling with gaining legitimacy when starting STEM ventures (Eddleston et al. 2016). Concerted efforts to increase business sustainability and the participation of 
women in startups offer a chance to increase the personal and collective wellbeing of women around the world.

Funding: This research received no external funding.

Conflicts of Interest: The author declares no conflict of interest.

\section{Appendix A}

sossman Accelerator Being succesful Business Model Business stage c.... Chilean Culture Coping Strategy

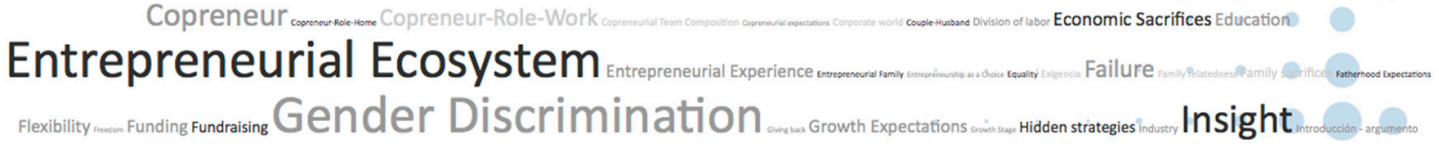

Investors Knowledge \& Skills - gender gaps LATAM culture

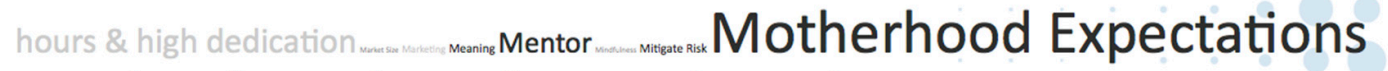

Motherhood in the tech industry motivation to start upa business

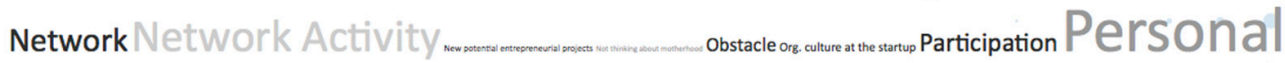

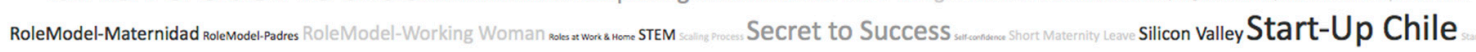

SupportTeam Team formation Tech-entrepreneurship world

*Work Role Work-Family Strategies

Figure A1. Open coding in a tag cloud.

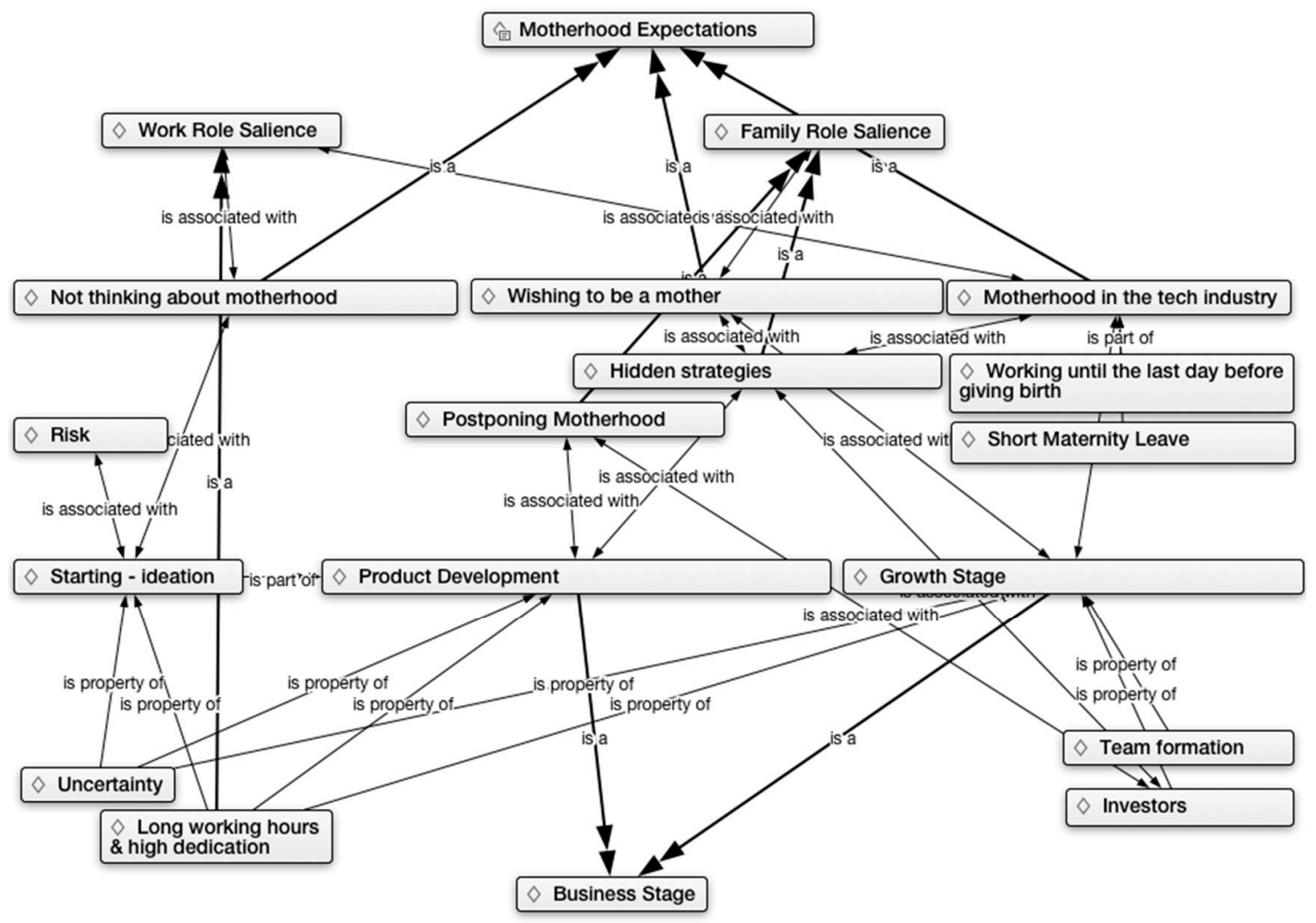

Figure A2. Axial and selected coding.

\section{References}

Adsera, Alicia, and Alicia Menendez. 2011. Fertility changes in Latin America in periods of economic uncertainty. Population Studies 65: 37-56. [CrossRef] [PubMed] 
Ahl, Helene J. 2002. The Making of the Female Entrepreneur: A Discourse Analysis of Research Texts on Women's Entrepreneurship. Jönköping: Jönköping University.

Aldrich, Howard E., and Jennifer E. Cliff. 2003. The pervasive effects of family on entrepreneurship: Toward a family embeddedness perspective. Journal of Business Venturing 18: 573-96. [CrossRef]

Annink, Anne, and Laura den Dulk. 2012. Autonomy: The panacea for self-employed women's work-life balance? Community Work E Family 15: 383-402.

Baker, Ted, Howard E. Aldrich, and Liou Nina. 1997. Invisible entrepreneurs: The neglect of women business owners by mass media and scholarly journals in the USA. Entrepreneurship E Regional Development 9: 221-38.

Bejian, Donna V., and Paul R. Salomone. 1995. Understanding Midlife Career Renewal: Implications for Counseling. The Career Development Quarterly 44: 52-63. [CrossRef]

Bernstein, Shai, Arthur Korteweg, and Kevin Laws. 2017. Attracting Early-Stage Investors: Evidence from a Randomized Field Experiment. The Journal of Finance 72: 509-38. [CrossRef]

Billing, Yvonne D. 2011. Are women in management victims of the phantom of the male norm? Gender, Work $\mathcal{E}$ Organization 18: 298-317.

Bird, Barbara, and Candida G. Brush. 2002. A gendered perspective on organizational creation. Entrepreneurship Theory and Practice 26: 41-65. [CrossRef]

Blank, Steven. 2010. What's A Startup? First Principles. Available online: http://steveblank.com/2010/01/25/ whats-a-startup-first-principles / (accessed on 31 March 2019).

Boden, Richard J., Jr. 1996. Gender and self-employment selection: An empirical assessment. Journal of Socio-Economics 25: 671-82. [CrossRef]

Boden, R. J., Jr. 1999. Flexible working hours, family responsibilities, and female self-employment. American Journal of Economics and Sociology 58: 71-83. [CrossRef]

Brown, Sarah, Lisa Farrel, and John G. Sessions. 2006. Self-employment matching: An analysis of dual earner couples and working households. Small Business Economics 26: 155-72. [CrossRef]

Brush, Candida G., Nancy M. Carter, Elizabeth J. Gatewood, Patricia G. Greene, and Myra Hart. 2004. Gatekeepers of Venture Growth: A Diana Project Report on the Role and Participation of Women in the Venture Capital Industry. Available online: http:/ / ssrn.com/abstract=1260385 (accessed on 31 March 2019).

Brush, Candida G., Abdul Ali, Donna Kelley, and Patricia Greene. 2017. The influence of human capital factors and context on women's entrepreneurship: Which matters more? Journal of Business Venturing Insights 8: 105-13. [CrossRef]

Budgeon, Shelley. 2015. Individualized Femininity and Feminist Politics of Choice. European Journal of Women's Studies 22: 303-18. [CrossRef]

Bullough, Amanda. 2013. Perceptions of Women Entrepreneurs in Male-Dominated Leadership Cultures: More Positive Support for Women than Many Thought. Journal of Enterprising Culture 21: 359-74. [CrossRef]

Burke, Peter J., and Donald C. Reitzes. 1991. An identity approach to commitment. Social Psychology Quarterly 54: 239-51. [CrossRef]

Byrne, Janice, Salma Fattoum, and María Cristina Diaz-García. 2019. Role models and women entrepreneurs: Entrepreneurial superwoman has her say. Journal of Small Business Management 57: 154-84. [CrossRef]

Carlson, Dawn S., and K. Michele Kacmar. 2000. Work-family conflict in the organization: Do life role values make a difference? Journal of Management 26: 1031-54. [CrossRef]

Carr, Deborah. 1996. Two paths to self-employment? Women's and men's self-employment in the United States, 1980. Work and Occupations 23: 26-53. [CrossRef]

Carter, Nancy M., and Kathleen R. Allen. 1997. Size determinants of women-owned businesses: Choice or barriers to resources? Entrepreneurship \& Regional Development 9: 211-20.

Charmaz, Kathy. 2006. Constructing Grounded Theory. Thousand Oaks: Sage Publications.

Cook, Ellen P. 1994. Role salience and multiple roles: A gender perspective. The Career Development Quarterly 43: 85-95. [CrossRef]

Corbin, Juliet, and Anselm Strauss. 2008. Basics of Qualitative Research, 3rd ed. Los Angeles: Sage.

Danes, Sharon M., Kathryn Stafford, George Haynes, and Sayali S. Amarapurkar. 2009. Family capital of family firms: Bridging human, social, and financial capital. Family Business Review 22: 199-216. [CrossRef]

Decker, Ryan, John Haltiwanger, Ron Jarmin, and Javier Miranda. 2014. The Role of Entrepreneurship in US Job Creation and Economic Dynamism. The Journal of Economic Perspectives 28: 3-24. [CrossRef] 
Demartini, Paola. 2018. Innovative Female-Led Startups. Do Women in Business Underperform? Administrative Sciences 8: 70. [CrossRef]

Demartini, Paola, and Lucia Marchegiani. 2018. Born to Be Alive? Female Entrepreneurship and Innovative Start-Ups. In Advances in Gender and Cultural Research in Business and Economics. Edited by Paola Paoloni and Rosa Lombardi. Cham: Springer, pp. 219-35.

Eagly, Alice H., and Mary C. Johannesen-Schmidt. 2001. The leadership styles of women and men. Journal of Social Issues 57: 781-97. [CrossRef]

Eddleston, Kimberly A., Jamie J. Ladge, Cheryl Mitteness, and Lakshmi Balachandra. 2016. Do you see what I See? Signaling effects of gender and firm characteristics on financing entrepreneurial ventures. Entrepreneurship Theory and Practice 8: 489-514. [CrossRef]

Gillespie, Rosemary. 2000. Disbelief, Disregard and Deviance as Discourses of Voluntary Childlessness. Women's Studies International Forum 23: 223-34. [CrossRef]

Glaser, Barney G., and Anslem L. Strauss. 1967. The Discovery of Grounded Theory: Strategies for Qualitative Research, 8th ed. New Brunswick: Transaction Publishers.

Gorbatai, Andreea, and Laura Nelson. 2015. The Narrative Advantage: Gender and the Language of Crowdfunding. Research Papers. Berkeley: Haas School of Business UC Berkeley.

Green, Eileen, and Laurie Cohen. 1995. 'Women's business': Are women entrepreneurs breaking new ground or simply balancing the demands of women's work' in a new way? Journal of Gender Studies 4: 297-314. [CrossRef]

Greene, Francis J., Liang Han, and Susan Marlow. 2013. Like mother, like daughter? Analyzing maternal influences upon women's entrepreneurial propensity. Entrepreneurship Theory and Practice 37: 687-711. [CrossRef]

Greenhaus, Jeffrey H., and Gary N. Powell. 2012. The family-relatedness of work decisions: A framework and agenda for theory and research. Journal of Vocational Behavior 80: 246-55. [CrossRef]

Greenhaus, Jeffrey H., Gerard. A. Callanan, and Veronica M. Godshalk. 2000. Career Management, 3rd ed. Fort Worth: Dryden Press.

Gustafsson, Siv, and Adriaan Kalwij, eds. 2006. Education and Postponement of Maternity: Economic Analyses for Industrialized Countries. Berlin: Springer Science \& Business Media, vol. 15.

Hastie, Reid. 2001. Problems for judgment and decision making. Annual Review of Psychology 52: 653-83. [CrossRef] [PubMed]

Jennings, Jennifer E., and Candida G. Brush. 2013. Research on Women Entrepreneurs: Challenges to (and from) the Broader Entrepreneurship Literature? The Academy of Management Annals 7: 663-715. [CrossRef]

Kariv, Dafna. 2013. Female Entrepreneurship and the New Venture Creation: An International Overview. London: Routledge.

Knaak, Stephanie J. 2010. Contextualising risk, constructing choice: Breastfeeding and good mothering in risk society. Health Risk \& Society 12: 345-55.

Kuschel, Katherina, and Juan Pablo Labra. 2018. Developing Entrepreneurial Identity among Start-ups' Female Founders in High-Tech: Policy Implications from the Chilean Case. In A Research Agenda for Women and Entrepreneurship: Identity through Aspirations, Behaviors, and Confidence. Edited by Patricia G. Greene and Candida G. Brush. Boston: Edward Elgar, pp. 27-44.

Kuschel, Katherina. 2019. Ecosystems enabling women entrepreneurs-Santiago, Chile. In The Wellbeing of Women in Entrepreneurship: A Global Perspective. Edited by María Teresa Lepeley, Katherina Kuschel, Nicholas Beutell, Nicky Pow and Emiel Eijdenberg. London: Routledge.

Kuschel, Katherina, and María Teresa Lepeley. 2016a. Women start-ups in technology: Literature review and research agenda to improve participation. International Journal of Entrepreneurship and Small Business 27: 333-46. [CrossRef]

Kuschel, Katherina, and María Teresa Lepeley. 2016b. Copreneurial Women in start-ups: Growth-oriented or lifestyle? An aid for technology industry investors. Academia Revista Latinoamericana de Administración 29: 1-19. [CrossRef]

Kuschel, Katherina, and Erica Salvaj. 2018. Opening the "Black Box". Factors Affecting Women's Journey to Top Management Positions: A Framework Applied to Chile. Administrative Sciences 8: 63. [CrossRef]

Kuschel, Katherina, María Teresa Lepeley, Fernanda Espinosa, and Sebastián Gutiérrez. 2017. Funding Challenges of Latin American Women Start-up Founders in the Technology Industry. Cross Cultural $\mathcal{E}$ Strategic Management 24: 310-31. 
Kuschel, Katherina, Juan Pablo Labra, and Gonzalo Diaz. 2018. Women-led startups and their contribution to job creation. In Technology Entrepreneurship_Insights in New Technology-Based Firms, Research Spin-Offs and Corporate Environments. Edited by Orestis Terzidis and André Presse. Cham: Springer.

Lepeley, María Teresa, Katherina Kuschel, Nicholas J. Beutell, Nicky Pouw, and Emiel Eijdenberg. 2019. The Wellbeing of Women in Entrepreneurship. A Global Perspective. London: Routledge.

Lewis, Patricia. 2014. Postfeminism, femininities and organization studies: Exploring a new agenda. Organization Studies 35: 1845-66. [CrossRef]

Lobel, Sharon A. 1991. Allocation of investment in work and family roles: Alternative theories and implications for research. Academy of Management Review 16: 507-21. [CrossRef]

Loscocco, Karyn A. 1997. Work-family linkages among self-employed women and men. Journal of Vocational Behavior 50: 204-26. [CrossRef]

Maher, JaneMaree, and Maryanne Dever. 2004. What Matters to Women: Beyond Reproductive Stereotypes. People and Place 12: 7-12.

Maher, JaneMaree, and Lise Saugeres. 2007. To be or not to be a mother? Women negotiating cultural representations of mothering. Journal of Sociology 43: 5-21. [CrossRef]

Marlow, Susan. 1997. Self-employed women-New opportunities, old challenges? Entrepreneurship E Regional Development 9: 199-210.

Marlow, Susan, and Maura McAdam. 2012. Analyzing the Influence of Gender upon High-Technology Venturing within the Context of Business Incubation. Entrepreneurship Theory and Practice 36: 655-76. [CrossRef]

Marlow, Susan, and Maura McAdam. 2015. Incubation or induction? Gendered identity work in the context of technology business incubation. Entrepreneurship Theory and Practice 39: 791-816. [CrossRef]

Matzeder, Mary E., and Thomas S. Krieshok. 1995. Career self-efficacy and the prediction of work and home role salience. Journal of Career Assessment 3: 331-40. [CrossRef]

Parasuraman, Saroj, Romila Singh, and Jeffrey H. Greenhaus. 1997. The influence of self and partner family variables on career development opportunities of professional women and men. In Australian Industrial and Organizational Psychology Conference. Edited by P. Tharenou. Melbourne: Australian Psychological Society, pp. 125-29.

Powell, Gary N., and Jeffrey H. Greenhaus. 2012. When family considerations influence work decisions: Decision-making processes. Journal of Vocational Behavior 81: 322-29. [CrossRef]

Prunty, Martine C., Louise Sharpe, Phyllis Butow, and Gary Fulcher. 2008. The motherhood choice: A decision aid for women with multiple sclerosis. Patient Education and Counseling 71: 108-15. [CrossRef] [PubMed]

Ries, Eric. 2011. The Lean Startup: How Today's Entrepreneurs Use Continuous Innovation to Create Radically Successful Businesses. New York: Crown Business.

Robb, Alicia, and Susan Coleman. 2009. Characteristics of New Firms: A Comparison by Gender. Available online: http:/ / ssrn.com/abstract=1352601 (accessed on 31 March 2019).

Rothbard, Nancy P., and Jeffrey R. Edwards. 2003. Investment in work and family roles: A test of identity and utilitarian motives. Personnel Psychology 56: 699-730. [CrossRef]

Schindehutte, Minet, Michael Morris, and Catriona Brennan. 2003. Entrepreneurs and Motherhood: Impacts on Their Children in South Africa and the United States. Journal of Small Business Management 41: 94-107. [CrossRef]

Singh Cassidy, Sukhinder. 2015. Tech Women Choose Possibility. Available online: http:/ / recode.net/2015/05/ 13/tech-women-choose-possibility/ (accessed on 31 March 2019).

Stryker, Sheldon, and Richard T. Serpe. 1994. Identity salience and psychological centrality: Equivalent, overlapping, or complementary concepts? Social Psychology Quarterly 57: 16-35. [CrossRef]

Sullivan, Sherry. E. 1999. The Changing Nature of Careers: A Review and Research Agenda. Journal of Management 25: 457-84. [CrossRef]

Susaeta, Lourdes, José Ramon Pin, Sandra Idrovo, Alvaro Espejo, María Belizón, Angela Gallifa, Marisa Aguirre, and Eugenio Avila-Pedrozo. 2013. Generation or culture? Work attitude drivers: An analysis in Latin America and Iberian countries. Cross Cultural Management: An International Journal 20: 321-60. [CrossRef]

Thoits, Peggy A. 1991. On merging identity theory and stress research. Social Psychology Quarterly 54: 101-12. [CrossRef]

Thornton, Davi J. 2011. Neuroscience, affect, and the entrepreneurialization of motherhood. Communication and Critical/Cultural Studies 8: 399-424. [CrossRef] 
Vincent, Carol, Stephen J. Ball, and Soile Pietikainen. 2004. Metropolitan Mothers: Mothers, Mothering and Paid Work. Women's Studies International Forum 27: 571-87. [CrossRef]

Voydanoff, Patricia. 1988. Work and family: A review and expanded conceptualization. In Work and family: Theory, Research, and Applications. Edited by Elizabeth B. Goldsmith. Newbury Park: Sage.

Watkins, C. Edward, and Linda Mezydylo Subich. 1995. Annual review, 1992-94: Career development, reciprocal work/non-work interaction, and women's workforce participation. Journal of Vocational Behavior 47: 109-63. [CrossRef]

West, Candace, and Don H. Zimmerman. 1987. Doing Gender. Gender and Society 1: 125-51. [CrossRef] 